Board of Governors of the Federal Reserve System

International Finance Discussion Papers

Number 1296

August 2020

\title{
Artificial Intelligence Methods for Evaluating Global Trade Flows
}

Feras A. Batarseh, Munisamy Gopinath, and Anderson Monken

Please cite this paper as:

Batarseh, Feras A., Munisamy Gopinath, and Anderson Monken (2020). "Artificial Intelligence Methods for Evaluating Global Trade Flows," International Finance Discussion Papers 1296. Washington: Board of Governors of the Federal Reserve System, https://doi.org/10.17016/IFDP.2020.1296.

NOTE: International Finance Discussion Papers (IFDPs) are preliminary materials circulated to stimulate discussion and critical comment. The analysis and conclusions set forth are those of the authors and do not indicate concurrence by other members of the research staff or the Board of Governors. References in publications to the International Finance Discussion Papers Series (other than acknowledgement) should be cleared with the author(s) to protect the tentative character of these papers. Recent IFDPs are available on the Web at www.federalreserve.gov/pubs/ifdp/. This paper can be downloaded without charge from the Social Science Research Network electronic library at www.ssrn.com. 


\title{
Artificial Intelligence Methods for Evaluating Global Trade Flows*
}

\section{Feras A. Batarseh ${ }^{\dagger}$}

\author{
Munisamy Gopinath
}

\begin{abstract}
International trade policies remain in the spotlight given the recent rethink on the benefits of globalization by major economies. Since trade critically affects employment, production, prices and wages, understanding and predicting future patterns of trade is a high-priority for decision making within and across countries. While traditional economic models aim to be reliable predictors, we consider the possibility that Artificial Intelligence (AI) techniques allow for better predictions and associations to inform policy decisions. Moreover, we outline contextual AI methods to decipher trade patterns affected by outlier events such as trade wars and pandemics. Open-government data are essential to providing the fuel to the algorithms that can forecast, recommend, and classify policies. Data collected for this study describe international trade transactions and commonly associated economic factors. Models deployed include Association Rules for grouping commodity pairs; and ARIMA, GBoosting, XGBoosting, and LightGBM for predicting future trade patterns. Models and their results are introduced and evaluated for prediction and association quality with example policy implications.
\end{abstract}

Keywords: AI, international trade, boosting, prediction, data mining, imports and exports, outlier events

JEL codes: F13, F17, C55, C8

\footnotetext{
* The views in this paper are solely the responsibility of the authors and should not be interpreted as reflecting the views of the Board of Governors of the Federal Reserve System or of any other person associated with the Federal Reserve System. We thank Rob Vigfusson for his valuable comments.

$\dagger$ Batarseh: College of Science, George Mason University. Fairfax, VA, USA. Email: fbatarse@gmu.edu

$\$$ Gopinath: Department of Agricultural and Applied Economics, University of Georgia. Athens, Georgia, USA.

Email: m.gopinath@uga.edu

$\S$ Monken: Division of International Finance, Federal Reserve Board. Washington, DC, USA. Email: anderson.e.monken@ frb.gov
} 


\section{Background and Motivation}

In recent years, many countries are concerned about rising trade deficits (value of exports less imports) and their implications for employment, production, and wages. For instance, the United States' goods and services trade deficit with China was $\$ 378.8$ billion in 2018 . Such numbers are forcing countries to either exit trade agreements or enforce tariffs, (e.g. Brexit, U.S. tariffs on Chinese goods). These shocks to global trade in commodities pose challenges to predict future trading patterns. International economics has a long history of improving our understanding of factors causing trade and the consequences of free flow of goods and services across countries. Nonetheless, the recent shocks to the free-trade regime raise questions on the quality of earlier predictions and their applicability in the context of large trade disputes. To address these challenges, this article, identifies AI techniques appropriate for the international trade setting and tests their validity in making high quality projections (Batarseh and Yang, 2018). Recent technological advancements in Artificial Intelligence (AI) as well as data democratization (Batarseh and Yang, 2020) have helped increase transparency, which is critical in the context of public decision-making. Given the Open Data and Big Data initiatives presented in 2008 and 2012 (White House, 2008), federal agencies are forced to share their data on public repositories such as www.data.gov, as well as many agency-specific repositories. The combination of data availability, AI advances and a contemporary context, i.e. trade wars, offer a unique opportunity to explore the applicability of AI techniques for nimble and improved trade projections to aid in decision-making.

The primary objective of the paper is to identify techniques most appropriate for economic forecasts, especially in the context of international trade, test their relevance using historical data on trade patterns and wherever appropriate, make quantitative and qualitative comparisons to current approaches.

\section{AI for Economics and International Trade}

Based on a recent study by the National Bureau of Economic Research (NBER), AI is only recently being applied to address economic issues. AI has been applied across multiple domains; it has been employed in addressing challenges in healthcare (Reddy and Aggarwal, 2015) (Batarseh and Latif, 2015), education (Niemi et al., 2018), and sports (Alamar, 2013). Athey and Imbens (2019) provide a detailed overview of AI techniques that economists should know about, but to date, AI applications to understand or predict patterns of international trade are limited (Gopinath, Batarseh and Beckman 2020). 
The few economic applications include Gevel et al. (2013) on the nexus between Artificial Intelligence and Economics; Feng et al. (2014) on economic growth in the Chinese province of Zhejiang; Abadie et al. (2010) to the rising economics of tobacco in California; Milacic et al. (2016) and Kordanuli et al. (2016) for GDP growth; and Falat et al. (2015) for economic patterns.

Within AI, Machine learning (ML), Deep Learning (DL), and Reinforcement Learning (RL) are 3 major pillars that have showed success in applications to various disciplines. ML for instance, is commonly understood as a number of computational algorithms that extract hidden insights from large sets of data.

DL is a set of bio-inspired methods that deploy neural networks to classify variable outputs, and allocate patterns that require extensive model training and hierarchical feature learning. RL however is a set of models that influence software agents to take action(s) in an environment in order to maximize the notion of cumulative reward and avoid punishment (using value functions).

In this study, multiple AI methods are applied to a big data set of international trade (imports/exports) with a focus on improved predictions. Experimental work presented in this paper utilizes AI methods in an optimized manner to provide predictions and associations regarding trade of specific commodities and countries (regressions, classifiers, clusters, associations and multiple other actionable outcomes). Given the dimensions of the data, and the high number of variables involved, several models are developed; few are compared to explain international trade patterns. Figure 1 illustrates top AI methods considered for this study.

Furthermore, the paper outlines approaches that are appropriate for the uncertain global trade environment in recent years. Trade wars between major economies, de-globalization trends, as well as the Covid19 pandemic have seriously disrupted flows of goods and services within and across countries. Contextual AI, appropriate for this setting, is also discussed as a possible application to the trade setting. 


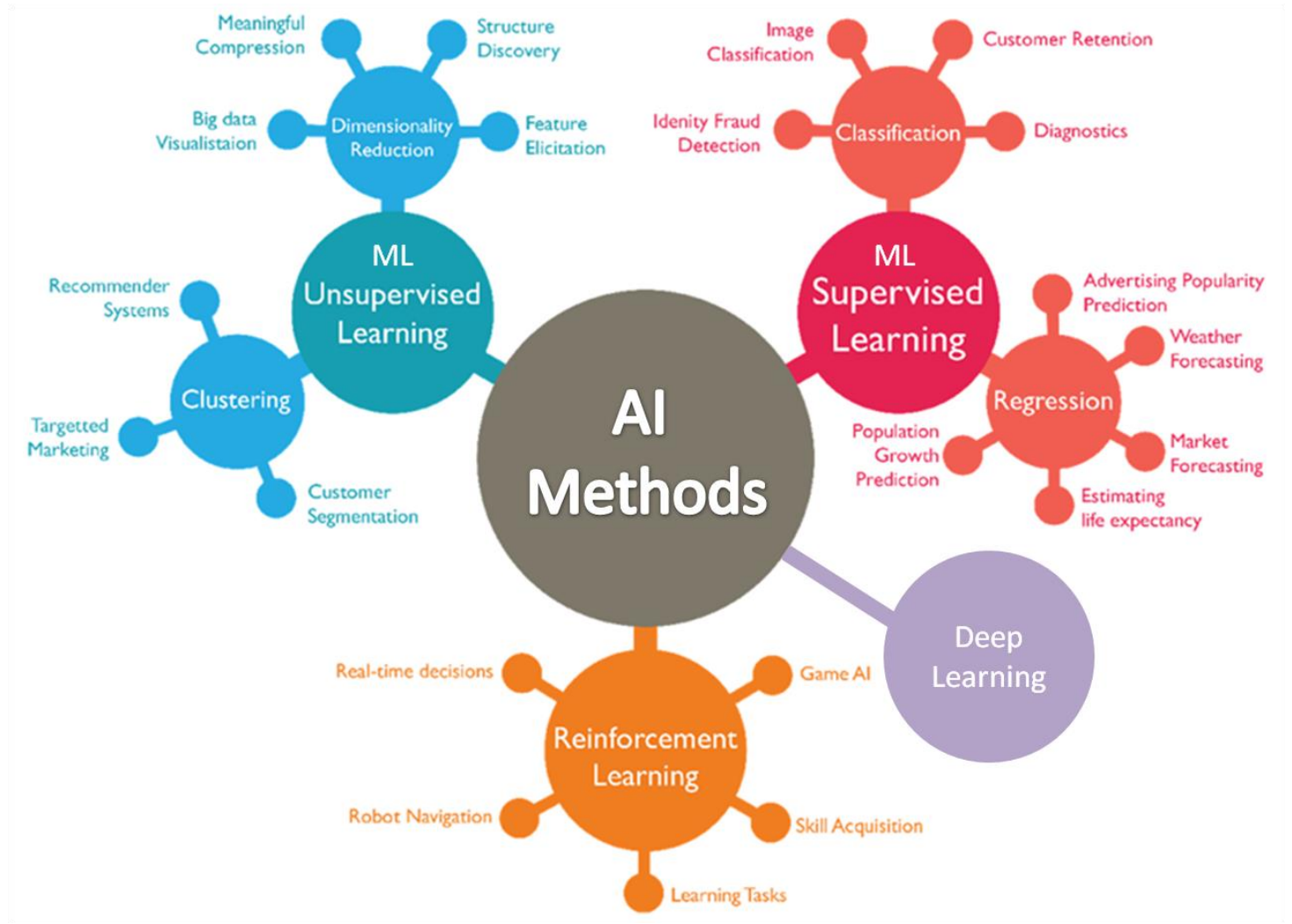

Figure 1: A Subset of the Most Commonplace AI Methods

\section{Data Collection and Pre-Processing}

For predictions using AI methods, data has been collected on several specific products - all the Harmonized System 4-digit level from USDA’s Foreign Agricultural Services' Global Agricultural Trade System (FAS - GATS) (USDA 2019). GATS is a system published by the United States Department of Agriculture. To apply supervised methods, additional economic data is collected from the World Bank's World Integrated Trade Solution (WITS 2019) and U.S. ITC's Gravity Portal (2019). The trade data cover seven major commodities with a long history of trade data (starting in the 1960s): Wheat, Milk, Rice, Corn, Beef, Soy, and Sugar. They are merged with 30+ economic variables, such as: Population, Currency, Island or Not, GDP of Origin, GDP of Destination, Distance, Landlocked or not, WTO Member, Hostility, EU Member, and other ones (U.S. ITC Gravity Portal).

Afterwards, the economic and commodity data are merged into a SQL database. An R code is used to merge on country-to-country trade transactions, as well as year of economic variables. The data are merged using a SQL Inner Join. The 30+ economic variables' correlations are studied; results for the 
correlations (done in R) are plotted in Figure 2. Highest economic correlations, for example, are found between: population and whether the country is an island, also, between currency and GDP, and between WTO membership and Free Trade Agreements; amongst other existing factors.

For Association Rules (AR), data come from the World Trade Organization (WTO) Bilateral Imports dataset, which comprises annual country to country trade data from 1996 to 2018. Data come from countries reporting imports from trading partners around the world. Only countries that are part of the WTO report imports (the sample of countries is $~ 190$ ). The AR application focused on the chapter level of the system: the 2-digit codes (HS-2). Data on the 96-chapter level trade products are downloaded from the WTO developer portal (https://apiportal.wto.org/). Using Pandas and Numpy libraries in Python, data are loaded into a PostgreSQL database for ease of analysis. The next two sections present the methods and the results of 1) Predictions and 2) Associations.

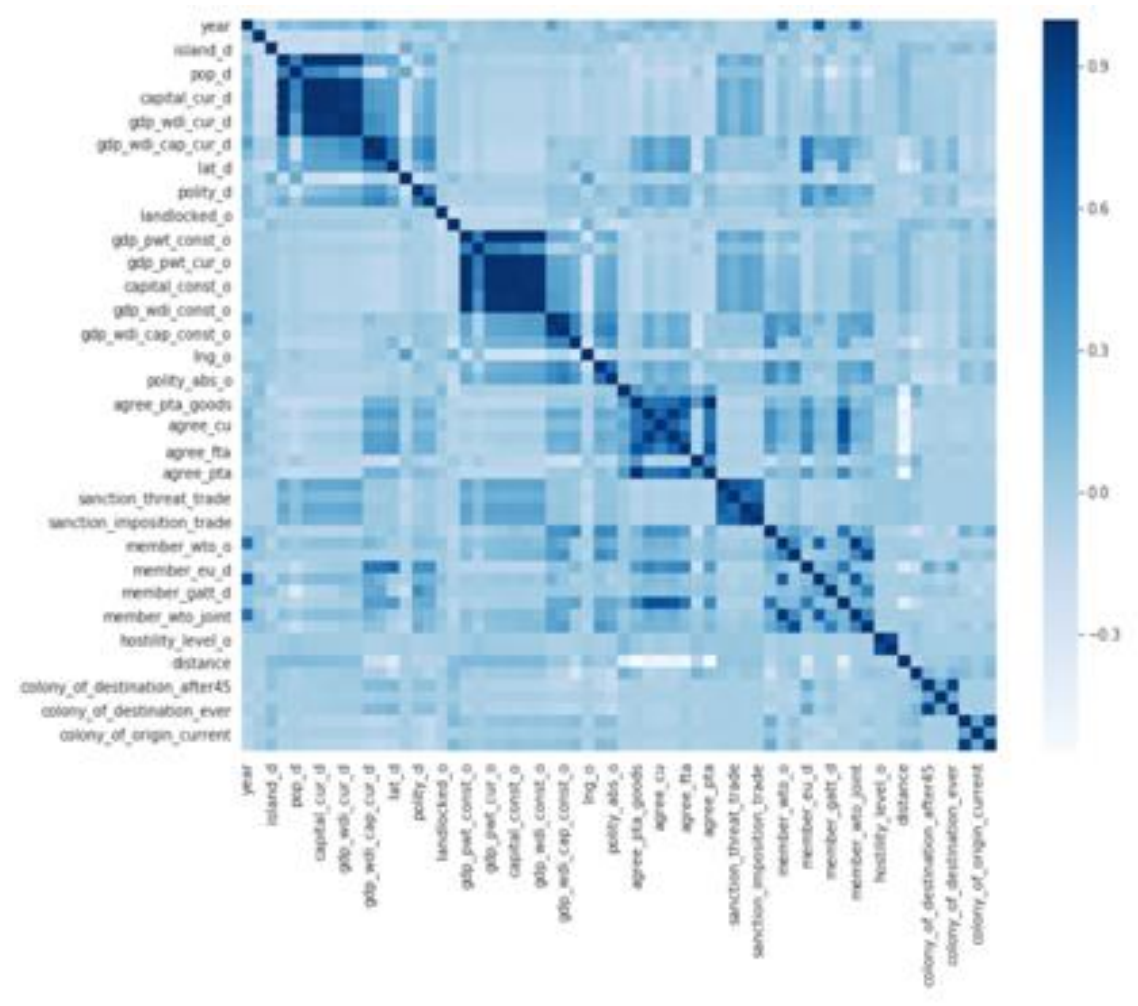

Figure 2: Correlations of 30+ Economic Variables 


\section{Predictions: Methods and Results}

Supervised and unsupervised methods have been explored: Linear Regression, K-means clustering, Pearson correlations, Boosting, and Time Series such as Autoregressive Integrated Moving Average (ARIMA). Simple linear regression modeling is applied to the seven major commodities mentioned; the aim is to predict exports or imports of a specific commodity. For example, after importing required columns into a python environment, linear regression is deployed using the python libraries: sklearn.linear_model and pandas (Python 2019).

The results below focus on one commodity: beef. Top countries exporting beef are: Australia, Germany, Netherlands, France, and United States. Although data for beef trade are available from 1960, data from 1989 to 2018 is used because of missing information on tariffs before 1988; years 2019-2021 are predicted (red line in Figure 3). As the figure illustrates, trade between nations is variant, and can change drastically over time; even for one commodity. Therefore, due to the high variance in the data, a simple regression model, although supervised, provides straight-line pointers to the future of beef trade (implying growth remains constant). Consequently, as an experimental model, an unsupervised K-means clustering model is developed to group countries into clusters (using sklearn's cluster and K-Means libraries in python).

Besides trade values, other economic variables are incrementally added to the modeling process. When all the economic variables are added, the aim is to identify which variables have the highest influence on trade predictions, and which ones could be controlled and tuned to change the forecasts. Different commodities had different rankings of economic variables, however, distance (between the 2 countries undergoing trade), population of the exporter, and GDP of both countries had the highest impact on whether two countries would trade one of the seven major commodities or not. Feature importance (Gain of top economic variables) is illustrated in Figure 4. Consequently, ARIMA is applied to beef trade, the advantage of ARIMA is that it provides univariate predictions that improve the output. ARIMA results are presented in Table 1 and Figure 5; they illustrate the high and low confidence intervals of the model. 


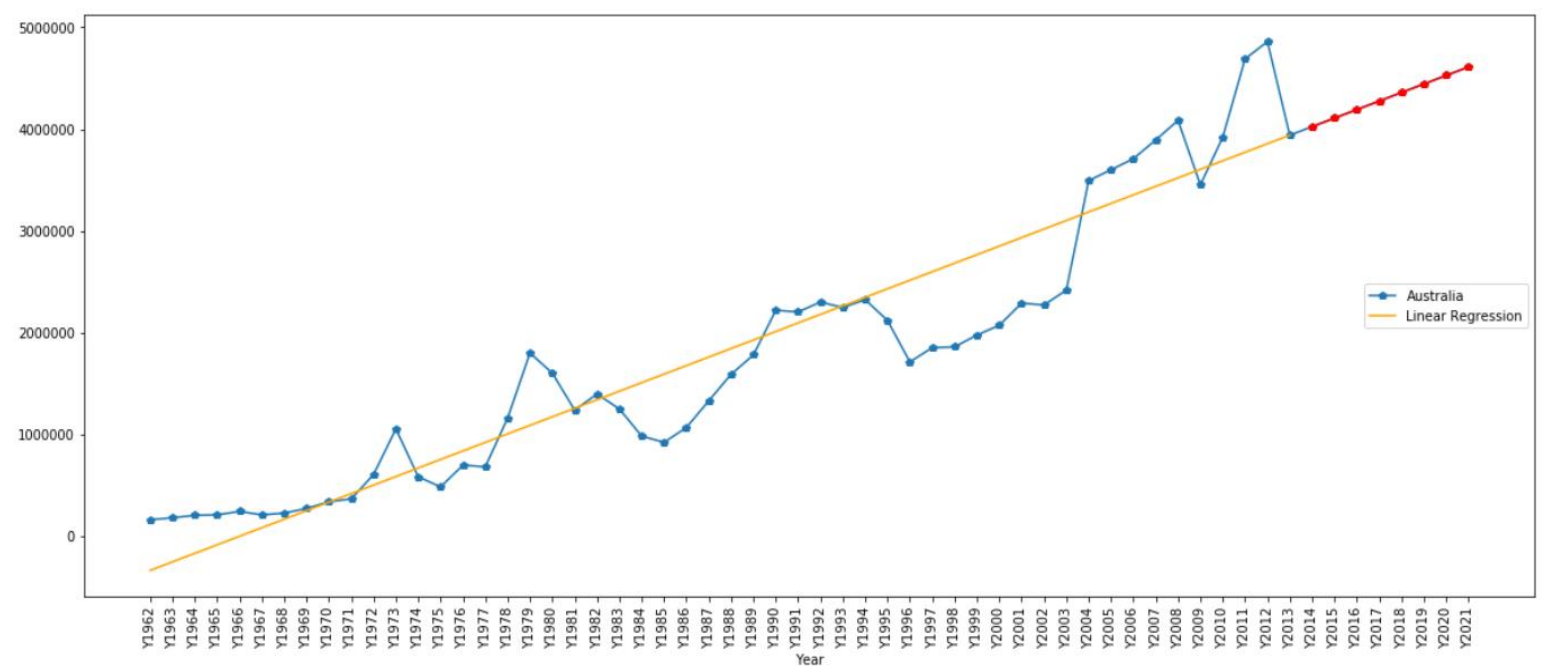

Figure 3: Australia’s Beef Exports 1988-2021

Afterwards, boosting has been applied to elevate the quality of the models. Three different boosting models are deployed: Gradient Boost (GBoost), Extreme Gradient Boosting (XGBoost), and Light Gradient Boosting Decision Tree (LightGBM). Python libraries are used to deploy the models (GBoost, XGBoost, and LightGBM) (Ke et al. 2017). After multiple iterations and hyper-parameters' tuning, LightGBM performed best for most commodities. A boosting algorithm is an algorithm that converts weak learners to strong learners. It is a method that improves predictions' quality of a model. Boosting trains weak learners sequentially, and in every cycle, each trying to correct its predecessor.

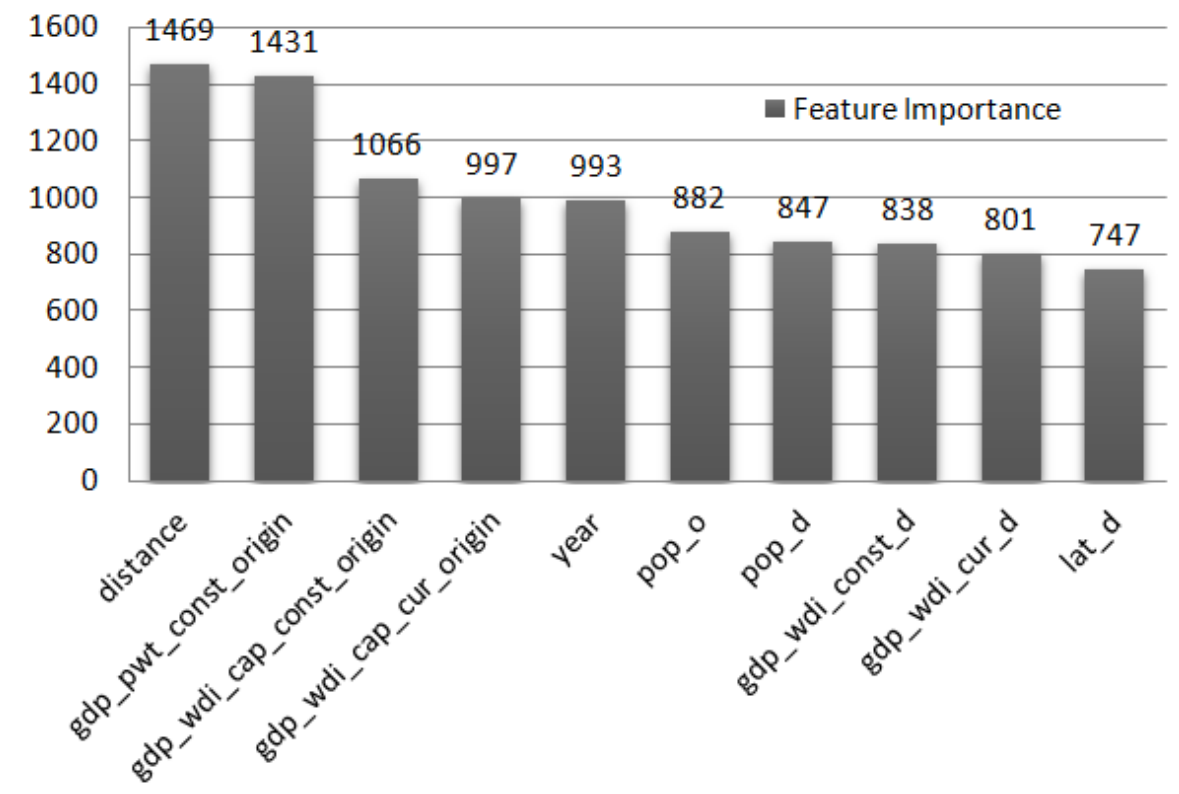

Figure 4: Strength of Variables in Predicting Trade Trends 
Table 1: ARIMA Forecasting of Beef Trade Trends

\begin{tabular}{|l|l|l|l|l|l|l|}
\hline Year & Actual & Forecast & Low 80 & High 80 & Low 95 & High 95 \\
\hline $\mathbf{2 0 1 4}$ & 6939233 & 5594243 & 5208462 & 5980024 & 5004242 & 6184244 \\
\hline $\mathbf{2 0 1 5}$ & 7357932 & 5698666 & 5153090 & 6244242 & 4864279 & 6533053 \\
\hline $\mathbf{2 0 1 6}$ & 5921218 & 5803089 & 5134898 & 6471281 & 4781178 & 6825000 \\
\hline $\mathbf{2 0 1 7}$ & 5843209 & 5907513 & 5135951 & 6679074 & 4727511 & 7087514 \\
\hline $\mathbf{2 0 1 8}$ & $\mathrm{X}$ & 6011936 & 5149304 & 6874567 & 4692654 & 7331217 \\
\hline $\mathbf{2 0 1 9}$ & $\mathrm{X}$ & 6116359 & 5171393 & 7061325 & 4671159 & 7561559 \\
\hline $\mathbf{2 0 2 0}$ & $\mathrm{X}$ & 6220782 & 5200102 & 7241462 & 4659787 & 7781777 \\
\hline $\mathbf{2 0 2 1}$ & $\mathrm{X}$ & 6325205 & 5234053 & 7416358 & 4656432 & 7993979 \\
\hline
\end{tabular}

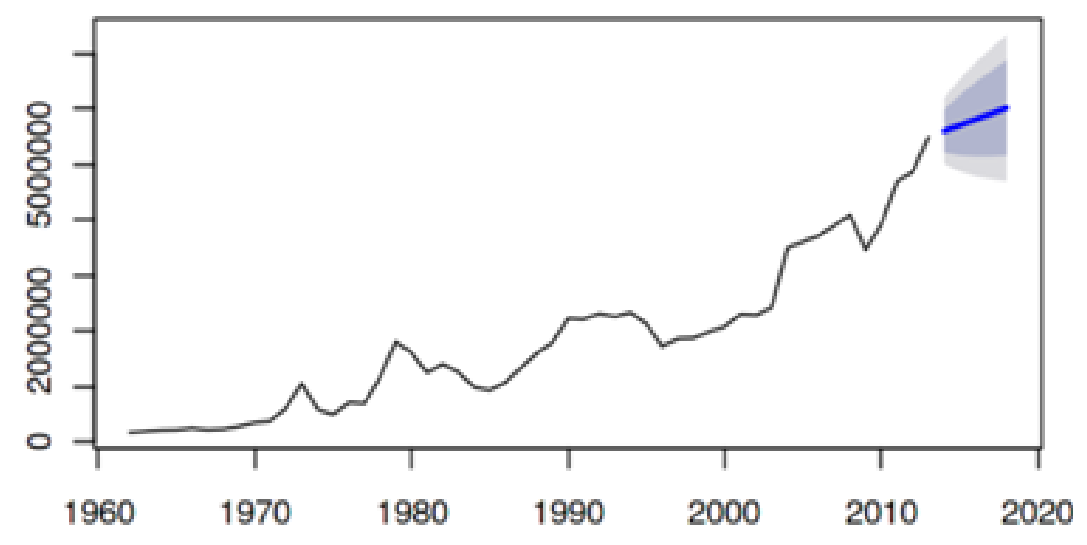

Figure 5: Australia's Beef Exports Predictions (ARIMA)

Results for trade predictions through the XGBoost Model scored predictions' quality $=69 \%$, and through LightGBM scored a quality of $\mathbf{8 8 \%}$ (in contrast, GBoost scored the lowest of the three approaches). Parameter tuning for boosting models include: Number of leaves, Maximum Depth of the tree, Learning Rate, and Feature fraction. Small learning rates are optimal (0.01), with large tree depths. Additionally, to speed up training and avoid over-fitting, feature fraction is set to 0.6 ; that is, selecting $60 \%$ of the features before training each tree. Early stopping round is set to 500; that allowed the model to train until the validation score stops improving. Maximum tree depth is set to 8 . Those tunings led to the best output through LightGBM. Sugar for instance had an $\mathrm{R}^{2}$ score of 0.73, 0.88 for Beef, and 0.66 for Corn. Additionally, such tunings allowed for the extractions of the best economic variables that would affect 
trade of specific commodities. As mentioned for beef for example, distance had the highest effect (i.e. the US is better off trading beef to Canada and Mexico, its two closest neighbors). While Australia, being an island, has to focus its policies for beef exports on GDP measures, and the population of the importer. Feature Importance for all economic variables are (name: split, gain.): Distance: 1469, 6.38. GDP of Exporter: 1431, 6.22. Year: 993, 4.318. Population of Exporter: 882, 3.83. Population of Importer: 847, 3.68. Currency of Importer: 801, 3.48. Figure 6 shows predictions for aggregate Australian exports of beef as well as its exports to the major trade partner: Japan.

The clustering model yielded very expected results: China and the US ended up in Cluster 1, as the biggest exporters and importers. Cluster 2 has other major exporters and importers: Japan, Germany, Canada, UK, India, and France. Cluster 3 has less important importer countries, such as most third-world countries.

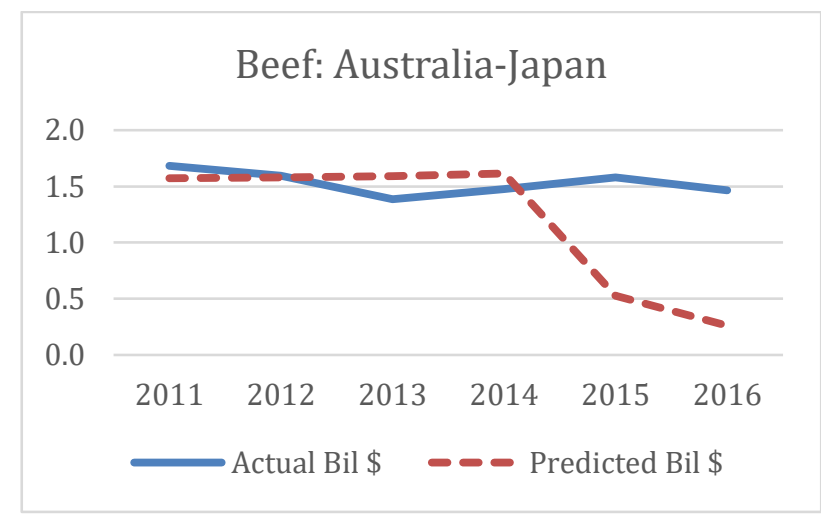

Figure 6(a): Supervised Model Projections

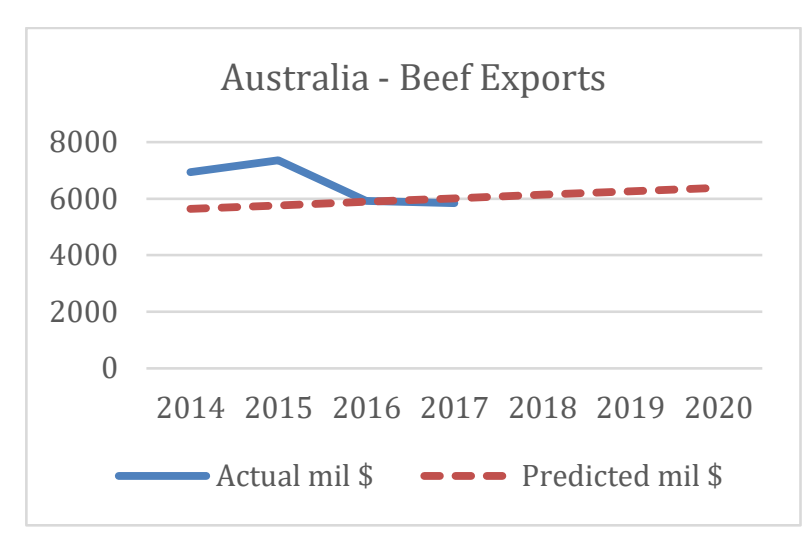

Figure 6(b): Unsupervised Model Projections

\section{Associations: Methods and Results}

Identifying commodities that are traded in association with each other point to substitutability and complementarities and has a direct implication on decision making when one commodity is targeted, e.g. U.S. soybeans or Chinese steel. AR is a popular method for discovering hidden relations between variables in big datasets. Piatetsky and Shapiro (1991) describe analyzing strong rules discovered in datasets. Based on the notion of strong rules, Agrawal et al. (1993) introduced the problem of mining association rules from transaction data.

The idea of $A R$ is as follows: Let $X=\left\{x_{1}, x_{2}, \ldots, x_{n}\right\}$ be a set of $n$ commodities. Let $T=\left\{t_{1}, t_{2}, \ldots, t_{n}\right\}$ be a set of transactions (where $T t$ is the total number of transactions). Each transaction in $\mathrm{T}$ has a unique 
ID and contains a subset of the commodities (X) that are traded. A rule is defined as an implication of the form $X_{a} \Rightarrow X_{b}$ where $X_{a}, X_{b} \subseteq X$ and $X_{a} \cap X_{b}=\varnothing$.

The sets of commodities $\mathrm{X}_{\mathrm{a}}$ is called antecedents (left-hand-side or LHS) and the set of commodities $\mathrm{X}_{\mathrm{b}}$ is called consequents (right-hand-side or RHS) of the rule.

Besides antecedent-consequent rules, the quality of the associations is measured through the following three metrics:

1. Support $=\frac{X_{a}+X_{b}}{T t}$

2. Confidence $=\frac{X_{a}+X_{b}}{X_{a}}$

3. Lift $=\frac{\left(X_{a}+X_{b}\right) / X_{a}}{\left(X_{b} / T t\right)}$

Support indicates that for example $67 \%$ of customers purchased beer and diapers together. Confidence is that $90 \%$ of the customers who bought beer also bought diapers (confidence is the best indicator of AR). While lift represents the $28 \%$ increase in expectation that someone will buy diapers, when we know that they bought beer (i.e. lift is the conditional probability).

In our study, AR mining is performed using the arules library in R. Data are pulled and processed from PostgreSQL. Transactions in the data represent each country-country pair's trade for a given year. The goods in the data are the 96 commodity code trade dummies, which are boolean values depending on whether trade occurred for a specific country-country pair for a given year. Apriori association rules are collected with a minimum support of 0.35 and a maximum number of antecedents set to 3 . Results are visualized in plotly and exported using R. The top $\mathbf{4}$ million+ rules are pulled out of the models, and migrated into a structured relational SQL database (called: AR-Trade). The rules are pulled for U.S. trade for top trade countries in Asia (China, Korea, and Japan); as well as the top trade countries in Europe (UK, Spain, France, and Germany). Relational SQL tables include the following columns:

Lhs (antecedent), Rhs (consequent), Lhs name, Rhs name, Support, Confidence, Lift, Count, Country_O, Country_D. AR results are plotted using an R-Shiny dashboard, as well as $\mathrm{R}$ plots using the arulesViz library such as through this script:

isS4(AR-Trade)

AR-Trade@lhs

plot (AR-Trade)

Results are recorded and analyzed. 
AR is applied to HS2 commodity codes, and so for instance, if beer leads to diapers at the grocery store, then oil seeds lead to cotton in international trade. In future work, we aim to deploy HS6 AR analysis to directly influence production decisions in the U.S., provide tariff insights, and other potential trade policies. Table 2 presents example top commodity pairs as antecedents and consequents.

Table 2: A Sample of Top AR Associations

\begin{tabular}{|c|c|c|c|}
\hline ID & Antecedent & Consequent & $\begin{array}{l}\text { Sum of } \\
\text { Confidence }\end{array}$ \\
\hline 1 & $\begin{array}{l}\text { Products of the milling industry; malt; } \\
\text { starches; inulin; wheat gluten }\end{array}$ & Knitted or crocheted fabrics & 935 \\
\hline 2 & $\begin{array}{l}\text { Animal or vegetable fats and oils and } \\
\text { their cleavage products; prepared edi- } \\
\text { ble fats; animal or vegetable waxes }\end{array}$ & Cereals & 902 \\
\hline 3 & $\begin{array}{l}\text { Animal or vegetable fats and oils and } \\
\text { their cleavage products; prepared edi- } \\
\text { ble fats; animal or vegetable waxes }\end{array}$ & Clocks and watches and parts thereof & 891 \\
\hline 4 & $\begin{array}{l}\text { Animal or vegetable fats and oils and } \\
\text { their cleavage products; prepared edi- } \\
\text { ble fats; animal or vegetable waxes }\end{array}$ & Cocoa and cocoa preparations & 883.71 \\
\hline 5 & $\begin{array}{l}\text { Animal or vegetable fats and oils and } \\
\text { their cleavage products; prepared edi- } \\
\text { ble fats; animal or vegetable waxes }\end{array}$ & Copper and articles thereof & 891 \\
\hline 6 & $\begin{array}{l}\text { Animal or vegetable fats and oils and } \\
\text { their cleavage products; prepared edi- } \\
\text { ble fats; animal or vegetable waxes }\end{array}$ & Cork and articles of cork & 879.71 \\
\hline 7 & $\begin{array}{l}\text { Animal or vegetable fats and oils and } \\
\text { their cleavage products; prepared edi- } \\
\text { ble fats; animal or vegetable waxes }\end{array}$ & Cotton & 891 \\
\hline 8 & $\begin{array}{l}\text { Animal or vegetable fats and oils and } \\
\text { their cleavage products; prepared edi- } \\
\text { ble fats; animal or vegetable waxes }\end{array}$ & $\begin{array}{l}\text { Electrical machinery and equipment and } \\
\text { parts thereof; sound recorders and repro- } \\
\text { ducers, television image and sound re- } \\
\text { corders and reproducers, and parts and } \\
\text { accessories of such articles }\end{array}$ & 891 \\
\hline 9 & $\begin{array}{l}\text { Animal or vegetable fats and oils and } \\
\text { their cleavage products; prepared edi- } \\
\text { ble fats; animal or vegetable waxes }\end{array}$ & $\begin{array}{l}\text { Essential oils and resinoids; perfumery, } \\
\text { cosmetic or toilet preparations }\end{array}$ & 891 \\
\hline 10 & $\begin{array}{l}\text { Animal or vegetable fats and oils and } \\
\text { their cleavage products; prepared edi- } \\
\text { ble fats; animal or vegetable waxes }\end{array}$ & $\begin{array}{l}\text { Explosives; pyrotechnic products; } \\
\text { matches; pyrophoric alloys; certain com- } \\
\text { bustible preparations }\end{array}$ & 891 \\
\hline
\end{tabular}

The next section digs deeper into AR, and presents examples on bilateral trade between China and Australia, USA and top world traders, as well as China's top food and agriculture commodities' associations. 


\section{Bilateral Association Results}

As discussed prior, ARs provide means to determine goods that are often traded together. This cause and effect analysis is especially important when countries choose to enact trade restrictions and tariffs against other nations. The effect of losing the trade of one commodity between two countries depends on that commodity's relative impact on other commodities' trade - how many other commodities get traded alongside it. Table 3 is an example that describes how AR can be used to analyze the effects of recent Chinese trade restrictions.

Tariffs imposed between countries can both have international effects while also resulting in domestic economic consequences. In May of 2020, China placed tariffs against Australian Barley and restricted import of Australian Beef in apparent retaliation for Australia's government echoing the calls of the international community to investigate Beijing's response to Covid-19. Using AR confirms the choice of commodities to target were statistically sound for China's economy, because beef and barley are not in the top commodities that most impact the Australian-Sino commodity trade flows, AR analysis is performed for imports of Chinese goods to Australia and vice-versa for 1996 to 2019 across all available HS-6 level commodities (count = 4615). Rule building confidence threshold is set to 0.8, support threshold at 0.35 and up to three antecedents are allowed per rule. A total of 5,676,885 rules resulted, and antecedents across these rules were summed to determine commodities that have the most impact on the Sino-Australian trade relationship. Table 3 shows the top 25 commodities and the appearance count of AR. More results are available in a Github public repository: https://github.com/fbatarsegmu/TradeAI.

Table 3: China-Australia Top Trade Associations (HS-6)

\begin{tabular}{|r|l|l|c|}
\hline Rule \# & Antecedent commodity & HS-6 Code & $\begin{array}{l}\text { Count } \\
\text { of } \\
\text { Rules }\end{array}$ \\
\hline $\mathbf{1}$ & $\begin{array}{l}\text { Cereals; rice, semi-milled or wholly milled, whether or not } \\
\text { polished or glazed }\end{array}$ & 100630 & 46990 \\
\hline $\mathbf{2}$ & $\begin{array}{l}\text { Peel; of citrus fruit or melons (including watermelons), } \\
\text { fresh, frozen, dried or provisionally preserved in brine, in } \\
\text { sulphur water and other preservative solutions }\end{array}$ & 081400 & 46927 \\
\hline $\mathbf{3}$ & $\begin{array}{l}\text { Vegetables, leguminous; beans (vigna spp., phaseolus spp.), } \\
\text { shelled or unshelled, uncooked or cooked by steaming or } \\
\text { boiling in water, frozen }\end{array}$ & 071022 & 46920 \\
\hline
\end{tabular}




\begin{tabular}{|c|c|c|c|}
\hline 4 & $\begin{array}{l}\text { Vegetables, leguminous; peas (pisum sativum), shelled or } \\
\text { unshelled, fresh or chilled }\end{array}$ & 070810 & 46920 \\
\hline 5 & $\begin{array}{l}\text { Fish; dried (whether or not salted but not smoked), n.e.s. in } \\
\text { item no. } 0305.51\end{array}$ & 030559 & 46875 \\
\hline 6 & Bamboo used primarily for plaiting & 140110 & 46832 \\
\hline 7 & $\begin{array}{l}\text { Vegetables, leguminous; n.e.s. in heading no. } 0713 \text {, shelled, } \\
\text { whether or not skinned or split, dried }\end{array}$ & 071390 & 46781 \\
\hline 8 & $\begin{array}{l}\text { Fish preparations; fish prepared or preserved, whole or in } \\
\text { pieces (but not minced), n.e.s. in heading no. } 1604\end{array}$ & 160419 & 46764 \\
\hline 9 & $\begin{array}{l}\text { Vegetable preparations; mushrooms, prepared or preserved } \\
\text { otherwise than by vinegar or acetic acid }\end{array}$ & 200310 & 46710 \\
\hline 10 & $\begin{array}{l}\text { Food preparations; tapioca and substitutes thereof, prepared } \\
\text { from starch in the form of flakes, grains, pearls, siftings or } \\
\text { similar }\end{array}$ & 190300 & 46677 \\
\hline 11 & $\begin{array}{l}\text { Flours and meals of oil seeds or oleaginous fruits; excluding } \\
\text { soya beans and mustard seeds }\end{array}$ & 120890 & 46590 \\
\hline 12 & $\begin{array}{l}\text { Vegetables and mixed vegetables; n.e.s. in heading no. 0711, } \\
\text { provisionally preserved but unsuitable in that state for imme- } \\
\text { diate consumption }\end{array}$ & 071190 & 46545 \\
\hline 13 & Fruit, edible; dates, fresh or dried & 080410 & 46512 \\
\hline 14 & $\begin{array}{l}\text { Vegetables, leguminous; (other than peas or beans), shelled } \\
\text { or unshelled, uncooked or cooked by steaming or boiling in } \\
\text { water, frozen }\end{array}$ & 071029 & 46482 \\
\hline 15 & $\begin{array}{l}\text { Vegetable roots and tubers; sweet potatoes, with high starch } \\
\text { or inulin content, whether or not sliced or in the form of pel- } \\
\text { lets, fresh or dried }\end{array}$ & 071420 & 46467 \\
\hline 16 & Fruit, edible; figs, fresh or dried & 080420 & 46443 \\
\hline$\overline{17}$ & $\begin{array}{l}\text { Meat preparations; of swine, meat or meat offal (including } \\
\text { mixtures), prepared or preserved, n.e.s. in heading no. } 1602\end{array}$ & 160249 & 46410 \\
\hline 18 & $\begin{array}{l}\text { Vegetable preparations; vegetables and mixtures of vegeta- } \\
\text { bles (excluding potatoes), prepared or preserved otherwise } \\
\text { than by vinegar or acetic acid, frozen }\end{array}$ & 200490 & 46405 \\
\hline 19 & $\begin{array}{l}\text { Vegetables, leguminous; n.e.s. in item no. } 0713.30 \text {, dried, } \\
\text { shelled, whether or not skinned or split }\end{array}$ & 071339 & 46324 \\
\hline 20 & $\begin{array}{l}\text { Vegetables; uncooked or cooked by steaming or boiling in } \\
\text { water, frozen, n.e.s. in chapter } 7\end{array}$ & 071080 & 46279 \\
\hline 21 & $\begin{array}{l}\text { Vegetables, leguminous; peas (pisum sativum), shelled or } \\
\text { unshelled, uncooked or cooked by steaming or boiling in } \\
\text { water, frozen }\end{array}$ & 071021 & 46251 \\
\hline 22 & $\begin{array}{l}\text { Fish; salted or in brine, but not dried or smoked, n.e.s. in } \\
\text { item no. } 0305.6\end{array}$ & 030569 & 46113 \\
\hline 23 & Vegetables, alliaceous; garlic, fresh or chilled & 070320 & 46113 \\
\hline 24 & $\begin{array}{l}\text { Vegetable oils; ground-nut oil and its fractions, other than } \\
\text { crude, whether or not refined, but not chemically modified }\end{array}$ & 150890 & 46069 \\
\hline
\end{tabular}




\begin{tabular}{|r|l|l|c|}
\hline $\mathbf{2 5}$ & $\begin{array}{l}\text { Vegetable preparations; beans, (not shelled), prepared or } \\
\text { preserved otherwise than by vinegar or acetic acid, not fro- } \\
\text { zen }\end{array}$ & 200559 & 46025 \\
\hline
\end{tabular}

Additionally, top HS-2 ARs from USA's bilateral trade with China, Japan, France, and Germany are presented in Table 4. Table 5 presents the top five results for China's food and agricultural commodities trade.

Table 4: USA Trade Associations with other Countries (HS-2)

\begin{tabular}{|c|c|c|c|c|}
\hline Antecedent 1 & Antecedent 2 & Consequent & $\begin{array}{l}\text { Coun- } \\
\text { try_O }\end{array}$ & $\begin{array}{l}\text { Coun- } \\
\text { try_D }\end{array}$ \\
\hline Ores, slag and ash & $\begin{array}{l}\text { Works of art, collectors' } \\
\text { pieces and antiques }\end{array}$ & $\begin{array}{l}\text { Mineral fuels, mineral } \\
\text { oils and products of } \\
\text { their distillation; bitu- } \\
\text { minous substances; } \\
\text { mineral waxes }\end{array}$ & USA & China \\
\hline $\begin{array}{l}\text { Mineral fuels, min- } \\
\text { eral oils and prod- } \\
\text { ucts of their distilla- } \\
\text { tion; bituminous } \\
\text { substances; mineral } \\
\text { waxes }\end{array}$ & $\begin{array}{l}\text { Works of art, collectors' } \\
\text { pieces and antiques }\end{array}$ & Ores, slag and ash & USA & China \\
\hline Ores, slag and ash & $\begin{array}{l}\text { Mineral fuels, mineral } \\
\text { oils and products of their } \\
\text { distillation; bituminous } \\
\text { substances; mineral } \\
\text { waxes }\end{array}$ & $\begin{array}{l}\text { Works of art, collectors' } \\
\text { pieces and antiques }\end{array}$ & USA & China \\
\hline Ores, slag and ash & $\begin{array}{l}\text { Works of art, collectors' } \\
\text { pieces and antiques }\end{array}$ & $\begin{array}{l}\text { Inorganic chemicals; } \\
\text { organic or inorganic } \\
\text { compounds of precious } \\
\text { metals, of rare earth } \\
\text { metals, of radioactive } \\
\text { elements or of isotopes }\end{array}$ & USA & China \\
\hline $\begin{array}{l}\text { Inorganic chemicals; } \\
\text { organic or inorganic } \\
\text { compounds of pre- } \\
\text { cious metals, of rare } \\
\text { earth metals, of ra- } \\
\text { dioactive elements } \\
\text { or of isotopes }\end{array}$ & $\begin{array}{l}\text { Works of art, collectors' } \\
\text { pieces and antiques }\end{array}$ & Ores, slag and ash & USA & China \\
\hline Ores, slag and ash & $\begin{array}{l}\text { Inorganic chemicals; or- } \\
\text { ganic or inorganic com- } \\
\text { pounds of precious met- } \\
\text { als, of rare earth metals, }\end{array}$ & $\begin{array}{l}\text { Works of art, collectors' } \\
\text { pieces and antiques }\end{array}$ & USA & China \\
\hline
\end{tabular}




\begin{tabular}{|c|c|c|c|c|}
\hline & $\begin{array}{l}\text { of radioactive elements } \\
\text { or of isotopes }\end{array}$ & & & \\
\hline $\begin{array}{l}\text { Mineral fuels, min- } \\
\text { eral oils and prod- } \\
\text { ucts of their distilla- } \\
\text { tion; bituminous } \\
\text { substances; mineral } \\
\text { waxes }\end{array}$ & $\begin{array}{l}\text { Works of art, collectors' } \\
\text { pieces and antiques }\end{array}$ & $\begin{array}{l}\text { Inorganic chemicals; } \\
\text { organic or inorganic } \\
\text { compounds of precious } \\
\text { metals, of rare earth } \\
\text { metals, of radioactive } \\
\text { elements or of isotopes } \\
\end{array}$ & USA & China \\
\hline $\begin{array}{l}\text { Inorganic chemicals; } \\
\text { organic or inorganic } \\
\text { compounds of pre- } \\
\text { cious metals, of rare } \\
\text { earth metals, of ra- } \\
\text { dioactive elements } \\
\text { or of isotopes }\end{array}$ & $\begin{array}{l}\text { Works of art, collectors' } \\
\text { pieces and antiques }\end{array}$ & $\begin{array}{l}\text { Mineral fuels, mineral } \\
\text { oils and products of } \\
\text { their distillation; bitu- } \\
\text { minous substances; } \\
\text { mineral waxes }\end{array}$ & USA & China \\
\hline $\begin{array}{l}\text { Mineral fuels, min- } \\
\text { eral oils and prod- } \\
\text { ucts of their distilla- } \\
\text { tion; bituminous } \\
\text { substances; mineral } \\
\text { waxes }\end{array}$ & $\begin{array}{l}\text { Inorganic chemicals; or- } \\
\text { ganic or inorganic com- } \\
\text { pounds of precious met- } \\
\text { als, of rare earth metals, } \\
\text { of radioactive elements } \\
\text { or of isotopes }\end{array}$ & $\begin{array}{l}\text { Works of art, collectors' } \\
\text { pieces and antiques }\end{array}$ & USA & China \\
\hline Ores, slag and ash & $\begin{array}{l}\text { Mineral fuels, mineral } \\
\text { oils and products of their } \\
\text { distillation; bituminous } \\
\text { substances; mineral } \\
\text { waxes }\end{array}$ & $\begin{array}{l}\text { Inorganic chemicals; } \\
\text { organic or inorganic } \\
\text { compounds of precious } \\
\text { metals, of rare earth } \\
\text { metals, of radioactive } \\
\text { elements or of isotopes }\end{array}$ & USA & China \\
\hline Ores, slag and ash & $\begin{array}{l}\text { Inorganic chemicals; or- } \\
\text { ganic or inorganic com- } \\
\text { pounds of precious met- } \\
\text { als, of rare earth metals, } \\
\text { of radioactive elements } \\
\text { or of isotopes }\end{array}$ & $\begin{array}{l}\text { Mineral fuels, mineral } \\
\text { oils and products of } \\
\text { their distillation; bitu- } \\
\text { minous substances; } \\
\text { mineral waxes }\end{array}$ & USA & China \\
\hline $\begin{array}{l}\text { Mineral fuels, min- } \\
\text { eral oils and prod- } \\
\text { ucts of their distilla- } \\
\text { tion; bituminous } \\
\text { substances; mineral } \\
\text { waxes }\end{array}$ & $\begin{array}{l}\text { Inorganic chemicals; or- } \\
\text { ganic or inorganic com- } \\
\text { pounds of precious met- } \\
\text { als, of rare earth metals, } \\
\text { of radioactive elements } \\
\text { or of isotopes }\end{array}$ & Ores, slag and ash & USA & China \\
\hline Ores, slag and ash & $\begin{array}{l}\text { Works of art, collectors' } \\
\text { pieces and antiques }\end{array}$ & Organic chemicals & USA & China \\
\hline Organic chemicals & $\begin{array}{l}\text { Works of art, collectors' } \\
\text { pieces and antiques }\end{array}$ & Ores, slag and ash & USA & China \\
\hline $\begin{array}{l}\text { Inorganic chemicals; } \\
\text { organic or inorganic }\end{array}$ & $\begin{array}{l}\text { Works of art, collectors' } \\
\text { pieces and antiques }\end{array}$ & $\begin{array}{l}\text { Mineral fuels, mineral } \\
\text { oils and products of }\end{array}$ & USA & France \\
\hline
\end{tabular}




\begin{tabular}{|c|c|c|c|c|}
\hline $\begin{array}{l}\text { compounds of pre- } \\
\text { cious metals, of rare } \\
\text { earth metals, of ra- } \\
\text { dioactive elements } \\
\text { or of isotopes }\end{array}$ & & $\begin{array}{l}\text { their distillation; bitu- } \\
\text { minous substances; } \\
\text { mineral waxes }\end{array}$ & & \\
\hline $\begin{array}{l}\text { Mineral fuels, min- } \\
\text { eral oils and prod- } \\
\text { ucts of their distilla- } \\
\text { tion; bituminous } \\
\text { substances; mineral } \\
\text { waxes }\end{array}$ & $\begin{array}{l}\text { Inorganic chemicals; or- } \\
\text { ganic or inorganic com- } \\
\text { pounds of precious met- } \\
\text { als, of rare earth metals, } \\
\text { of radioactive elements } \\
\text { or of isotopes }\end{array}$ & $\begin{array}{l}\text { Works of art, collectors' } \\
\text { pieces and antiques }\end{array}$ & USA & France \\
\hline $\begin{array}{l}\text { Mineral fuels, min- } \\
\text { eral oils and prod- } \\
\text { ucts of their distilla- } \\
\text { tion; bituminous } \\
\text { substances; mineral } \\
\text { waxes }\end{array}$ & $\begin{array}{l}\text { Works of art, collectors' } \\
\text { pieces and antiques }\end{array}$ & Organic chemicals & USA & France \\
\hline Organic chemicals & $\begin{array}{l}\text { Works of art, collectors' } \\
\text { pieces and antiques }\end{array}$ & $\begin{array}{l}\text { Mineral fuels, mineral } \\
\text { oils and products of } \\
\text { their distillation; bitu- } \\
\text { minous substances; } \\
\text { mineral waxes }\end{array}$ & USA & France \\
\hline $\begin{array}{l}\text { Mineral fuels, min- } \\
\text { eral oils and prod- } \\
\text { ucts of their distilla- } \\
\text { tion; bituminous } \\
\text { substances; mineral } \\
\text { waxes }\end{array}$ & Organic chemicals & $\begin{array}{l}\text { Works of art, collectors' } \\
\text { pieces and antiques }\end{array}$ & USA & France \\
\hline $\begin{array}{l}\text { Inorganic chemicals; } \\
\text { organic or inorganic } \\
\text { compounds of pre- } \\
\text { cious metals, of rare } \\
\text { earth metals, of ra- } \\
\text { dioactive elements } \\
\text { or of isotopes }\end{array}$ & $\begin{array}{l}\text { Works of art, collectors' } \\
\text { pieces and antiques }\end{array}$ & Organic chemicals & USA & France \\
\hline Organic chemicals & $\begin{array}{l}\text { Works of art, collectors' } \\
\text { pieces and antiques }\end{array}$ & $\begin{array}{l}\text { Inorganic chemicals; } \\
\text { organic or inorganic } \\
\text { compounds of precious } \\
\text { metals, of rare earth } \\
\text { metals, of radioactive } \\
\text { elements or of isotopes }\end{array}$ & $\overline{\text { USA }}$ & France \\
\hline $\begin{array}{l}\text { Inorganic chemicals; } \\
\text { organic or inorganic } \\
\text { compounds of pre- } \\
\text { cious metals, of rare }\end{array}$ & Organic chemicals & $\begin{array}{l}\text { Works of art, collectors' } \\
\text { pieces and antiques }\end{array}$ & USA & France \\
\hline
\end{tabular}




\begin{tabular}{|c|c|c|c|c|}
\hline $\begin{array}{l}\text { earth metals, of ra- } \\
\text { dioactive elements } \\
\text { or of isotopes }\end{array}$ & & & & \\
\hline $\begin{array}{l}\text { Mineral fuels, min- } \\
\text { eral oils and prod- } \\
\text { ucts of their distilla- } \\
\text { tion; bituminous } \\
\text { substances; mineral } \\
\text { waxes }\end{array}$ & $\begin{array}{l}\text { Inorganic chemicals; or- } \\
\text { ganic or inorganic com- } \\
\text { pounds of precious met- } \\
\text { als, of rare earth metals, } \\
\text { of radioactive elements } \\
\text { or of isotopes }\end{array}$ & Organic chemicals & $\overline{U S A}$ & France \\
\hline $\begin{array}{l}\text { Mineral fuels, min- } \\
\text { eral oils and prod- } \\
\text { ucts of their distilla- } \\
\text { tion; bituminous } \\
\text { substances; mineral } \\
\text { waxes }\end{array}$ & Organic chemicals & $\begin{array}{l}\text { Inorganic chemicals; } \\
\text { organic or inorganic } \\
\text { compounds of precious } \\
\text { metals, of rare earth } \\
\text { metals, of radioactive } \\
\text { elements or of isotopes }\end{array}$ & $\overline{U S A}$ & France \\
\hline $\begin{array}{l}\text { Inorganic chemicals; } \\
\text { organic or inorganic } \\
\text { compounds of pre- } \\
\text { cious metals, of rare } \\
\text { earth metals, of ra- } \\
\text { dioactive elements } \\
\text { or of isotopes }\end{array}$ & Organic chemicals & $\begin{array}{l}\text { Mineral fuels, mineral } \\
\text { oils and products of } \\
\text { their distillation; bitu- } \\
\text { minous substances; } \\
\text { mineral waxes }\end{array}$ & USA & France \\
\hline $\begin{array}{l}\text { Mineral fuels, min- } \\
\text { eral oils and prod- } \\
\text { ucts of their distilla- } \\
\text { tion; bituminous } \\
\text { substances; mineral } \\
\text { waxes }\end{array}$ & $\begin{array}{l}\text { Works of art, collectors' } \\
\text { pieces and antiques }\end{array}$ & $\begin{array}{l}\text { Pharmaceutical prod- } \\
\text { ucts }\end{array}$ & USA & France \\
\hline $\begin{array}{l}\text { Pharmaceutical } \\
\text { products }\end{array}$ & $\begin{array}{l}\text { Works of art, collectors' } \\
\text { pieces and antiques }\end{array}$ & $\begin{array}{l}\text { Mineral fuels, mineral } \\
\text { oils and products of } \\
\text { their distillation; bitu- } \\
\text { minous substances; } \\
\text { mineral waxes }\end{array}$ & $\overline{U S A}$ & France \\
\hline Glass and glassware & $\begin{array}{l}\text { Natural or cultured } \\
\text { pearls, precious or semi- } \\
\text { precious stones, precious } \\
\text { metals, metals clad with } \\
\text { precious metal, and arti- } \\
\text { cles thereof; imitation } \\
\text { jewellery; coin }\end{array}$ & Ceramic products & USA & $\begin{array}{l}\text { Ger- } \\
\text { many }\end{array}$ \\
\hline Ceramic products & $\begin{array}{l}\text { Natural or cultured } \\
\text { pearls, precious or semi- } \\
\text { precious stones, precious } \\
\text { metals, metals clad with }\end{array}$ & Glass and glassware & $\overline{\mathrm{USA}}$ & $\begin{array}{l}\text { Ger- } \\
\text { many }\end{array}$ \\
\hline
\end{tabular}




\begin{tabular}{|c|c|c|c|c|}
\hline & $\begin{array}{l}\text { precious metal, and arti- } \\
\text { cles thereof; imitation } \\
\text { jewellery; coin }\end{array}$ & & & \\
\hline Ceramic products & Glass and glassware & $\begin{array}{l}\text { Natural or cultured } \\
\text { pearls, precious or sem- } \\
\text { iprecious stones, pre- } \\
\text { cious metals, metals } \\
\text { clad with precious } \\
\text { metal, and articles } \\
\text { thereof; imitation jewel- } \\
\text { lery; coin }\end{array}$ & USA & $\begin{array}{l}\text { Ger- } \\
\text { many }\end{array}$ \\
\hline Glass and glassware & $\begin{array}{l}\text { Natural or cultured } \\
\text { pearls, precious or semi- } \\
\text { precious stones, precious } \\
\text { metals, metals clad with } \\
\text { precious metal, and arti- } \\
\text { cles thereof; imitation } \\
\text { jewellery; coin }\end{array}$ & $\begin{array}{l}\text { Articles of stone, plas- } \\
\text { ter, cement, asbestos, } \\
\text { mica or similar materi- } \\
\text { als }\end{array}$ & USA & $\begin{array}{l}\text { Ger- } \\
\text { many }\end{array}$ \\
\hline $\begin{array}{l}\text { Articles of stone, } \\
\text { plaster, cement, as- } \\
\text { bestos, mica or simi- } \\
\text { lar materials }\end{array}$ & $\begin{array}{l}\text { Natural or cultured } \\
\text { pearls, precious or semi- } \\
\text { precious stones, precious } \\
\text { metals, metals clad with } \\
\text { precious metal, and arti- } \\
\text { cles thereof; imitation } \\
\text { jewellery; coin }\end{array}$ & Glass and glassware & USA & $\begin{array}{l}\text { Ger- } \\
\text { many }\end{array}$ \\
\hline $\begin{array}{l}\text { Articles of stone, } \\
\text { plaster, cement, as- } \\
\text { bestos, mica or simi- } \\
\text { lar materials }\end{array}$ & Glass and glassware & $\begin{array}{l}\text { Natural or cultured } \\
\text { pearls, precious or sem- } \\
\text { iprecious stones, pre- } \\
\text { cious metals, metals } \\
\text { clad with precious } \\
\text { metal, and articles } \\
\text { thereof; imitation jewel- } \\
\text { lery; coin }\end{array}$ & $\overline{\text { USA }}$ & $\begin{array}{l}\text { Ger- } \\
\text { many }\end{array}$ \\
\hline Glass and glassware & $\begin{array}{l}\text { Natural or cultured } \\
\text { pearls, precious or semi- } \\
\text { precious stones, precious } \\
\text { metals, metals clad with } \\
\text { precious metal, and arti- } \\
\text { cles thereof; imitation } \\
\text { jewellery; coin }\end{array}$ & $\begin{array}{l}\text { Prepared feathers and } \\
\text { down and articles made } \\
\text { of feathers or of down; } \\
\text { artificial flowers; arti- } \\
\text { cles of human hair }\end{array}$ & USA & $\begin{array}{l}\text { Ger- } \\
\text { many }\end{array}$ \\
\hline $\begin{array}{l}\text { Prepared feathers } \\
\text { and down and arti- } \\
\text { cles made of feathers } \\
\text { or of down; artificial } \\
\text { flowers; articles of } \\
\text { human hair }\end{array}$ & $\begin{array}{l}\text { Natural or cultured } \\
\text { pearls, precious or semi- } \\
\text { precious stones, precious } \\
\text { metals, metals clad with }\end{array}$ & Glass and glassware & $\overline{\text { USA }}$ & $\begin{array}{l}\text { Ger- } \\
\text { many }\end{array}$ \\
\hline
\end{tabular}




\begin{tabular}{|c|c|c|c|c|}
\hline & $\begin{array}{l}\text { precious metal, and arti- } \\
\text { cles thereof; imitation } \\
\text { jewellery; coin }\end{array}$ & & & \\
\hline $\begin{array}{l}\text { Prepared feathers } \\
\text { and down and arti- } \\
\text { cles made of feathers } \\
\text { or of down; artificial } \\
\text { flowers; articles of } \\
\text { human hair }\end{array}$ & Glass and glassware & $\begin{array}{l}\text { Natural or cultured } \\
\text { pearls, precious or sem- } \\
\text { iprecious stones, pre- } \\
\text { cious metals, metals } \\
\text { clad with precious } \\
\text { metal, and articles } \\
\text { thereof; imitation jewel- } \\
\text { lery; coin }\end{array}$ & USA & $\begin{array}{l}\text { Ger- } \\
\text { many }\end{array}$ \\
\hline Glass and glassware & $\begin{array}{l}\text { Natural or cultured } \\
\text { pearls, precious or semi- } \\
\text { precious stones, precious } \\
\text { metals, metals clad with } \\
\text { precious metal, and arti- } \\
\text { cles thereof; imitation } \\
\text { jewellery; coin }\end{array}$ & $\begin{array}{l}\text { Umbrellas, sun umbrel- } \\
\text { las, walking sticks, seat } \\
\text { sticks, whips, riding } \\
\text { cropsand parts thereof }\end{array}$ & USA & $\begin{array}{l}\text { Ger- } \\
\text { many }\end{array}$ \\
\hline $\begin{array}{l}\text { Umbrellas, sun um- } \\
\text { brellas, walking } \\
\text { sticks, seat sticks, } \\
\text { whips, riding crops } \\
\text { and parts thereof }\end{array}$ & $\begin{array}{l}\text { Natural or cultured } \\
\text { pearls, precious or semi- } \\
\text { precious stones, precious } \\
\text { metals, metals clad with } \\
\text { precious metal, and arti- } \\
\text { cles thereof; imitation } \\
\text { jewellery; coin }\end{array}$ & Glass and glassware & USA & $\begin{array}{l}\text { Ger- } \\
\text { many }\end{array}$ \\
\hline Glass and glassware & $\begin{array}{l}\text { Natural or cultured } \\
\text { pearls, precious or semi- } \\
\text { precious stones, precious } \\
\text { metals, metals clad with } \\
\text { precious metal, and arti- } \\
\text { cles thereof; imitation } \\
\text { jewellery; coin }\end{array}$ & Ceramic products & USA & Japan \\
\hline Ceramic products & $\begin{array}{l}\text { Natural or cultured } \\
\text { pearls, precious or semi- } \\
\text { precious stones, precious } \\
\text { metals, metals clad with } \\
\text { precious metal, and arti- } \\
\text { cles thereof; imitation } \\
\text { jewellery; coin }\end{array}$ & Glass and glassware & USA & Japan \\
\hline Ceramic products & Glass and glassware & $\begin{array}{l}\text { Natural or cultured } \\
\text { pearls, precious or sem- } \\
\text { iprecious stones, pre- } \\
\text { cious metals, metals } \\
\text { clad with precious } \\
\text { metal, and articles }\end{array}$ & USA & Japan \\
\hline
\end{tabular}




\begin{tabular}{|c|c|c|c|c|}
\hline & & $\begin{array}{l}\text { thereof; imitation jewel- } \\
\text { lery; coin }\end{array}$ & & \\
\hline Glass and glassware & $\begin{array}{l}\text { Natural or cultured } \\
\text { pearls, precious or semi- } \\
\text { precious stones, precious } \\
\text { metals, metals clad with } \\
\text { precious metal, and arti- } \\
\text { cles thereof; imitation } \\
\text { jewellery; coin }\end{array}$ & $\begin{array}{l}\text { Articles of stone, plas- } \\
\text { ter, cement, asbestos, } \\
\text { mica or similar materi- } \\
\text { als }\end{array}$ & USA & Japan \\
\hline $\begin{array}{l}\text { Articles of stone, } \\
\text { plaster, cement, as- } \\
\text { bestos, mica or simi- } \\
\text { lar materials }\end{array}$ & $\begin{array}{l}\text { Natural or cultured } \\
\text { pearls, precious or semi- } \\
\text { precious stones, precious } \\
\text { metals, metals clad with } \\
\text { precious metal, and arti- } \\
\text { cles thereof; imitation } \\
\text { jewellery; coin }\end{array}$ & Glass and glassware & USA & Japan \\
\hline $\begin{array}{l}\text { Articles of stone, } \\
\text { plaster, cement, as- } \\
\text { bestos, mica or simi- } \\
\text { lar materials }\end{array}$ & Glass and glassware & $\begin{array}{l}\text { Natural or cultured } \\
\text { pearls, precious or sem- } \\
\text { iprecious stones, pre- } \\
\text { cious metals, metals } \\
\text { clad with precious } \\
\text { metal, and articles } \\
\text { thereof; imitation jewel- } \\
\text { lery; coin }\end{array}$ & USA & Japan \\
\hline Glass and glassware & $\begin{array}{l}\text { Natural or cultured } \\
\text { pearls, precious or semi- } \\
\text { precious stones, precious } \\
\text { metals, metals clad with } \\
\text { precious metal, and arti- } \\
\text { cles thereof; imitation } \\
\text { jewellery; coin }\end{array}$ & $\begin{array}{l}\text { Prepared feathers and } \\
\text { down and articles made } \\
\text { of feathers or of down; } \\
\text { artificial flowers; arti- } \\
\text { cles of human hair }\end{array}$ & USA & Japan \\
\hline $\begin{array}{l}\text { Prepared feathers } \\
\text { and down and arti- } \\
\text { cles made of feathers } \\
\text { or of down; artificial } \\
\text { flowers; articles of } \\
\text { human hair }\end{array}$ & $\begin{array}{l}\text { Natural or cultured } \\
\text { pearls, precious or semi- } \\
\text { precious stones, precious } \\
\text { metals, metals clad with } \\
\text { precious metal, and arti- } \\
\text { cles thereof; imitation } \\
\text { jewellery; coin }\end{array}$ & Glass and glassware & USA & Japan \\
\hline $\begin{array}{l}\text { Prepared feathers } \\
\text { and down and arti- } \\
\text { cles made of feathers } \\
\text { or of down; artificial } \\
\text { flowers; articles of } \\
\text { human hair }\end{array}$ & Glass and glassware & $\begin{array}{l}\text { Natural or cultured } \\
\text { pearls, precious or sem- } \\
\text { iprecious stones, pre- } \\
\text { cious metals, metals } \\
\text { clad with precious } \\
\text { metal, and articles } \\
\text { thereof; imitation jewel- } \\
\text { lery; coin }\end{array}$ & USA & Japan \\
\hline
\end{tabular}




\begin{tabular}{|l|l|l|l|l|}
\hline Glass and glassware & $\begin{array}{l}\text { Natural or cultured } \\
\text { pearls, precious or semi- } \\
\text { precious stones, precious } \\
\text { metals, metals clad with } \\
\text { precious metal, and arti- } \\
\text { cles thereof; imitation } \\
\text { jewellery; coin }\end{array}$ & $\begin{array}{l}\text { Umbrellas, sun umbrel- } \\
\text { las, walking sticks, seat } \\
\text { sticks, whips, riding } \\
\text { crops and parts thereof }\end{array}$ & USA & Japan \\
\hline $\begin{array}{l}\text { Umbrellas, sun um- } \\
\text { brellas, walking } \\
\text { sticks, seat sticks, } \\
\text { whips, riding crops } \\
\text { and parts thereof }\end{array}$ & $\begin{array}{l}\text { Natural or cultured } \\
\text { pearls, precious or semi- } \\
\text { precious stones, precious } \\
\text { metals, metals clad with } \\
\text { precious metal, and arti- } \\
\text { cles thereof; imitation } \\
\text { jewellery; coin }\end{array}$ & Glass and glassware & USA & Japan \\
\hline $\begin{array}{l}\text { Umbrellas, sun um- } \\
\text { brellas, walking } \\
\text { sticks, seat sticks, } \\
\text { whips, riding crops } \\
\text { and parts thereof }\end{array}$ & Glass and glassware & $\begin{array}{l}\text { Natural or cultured } \\
\text { pearls, precious or sem- } \\
\text { iprecious stones, pre- } \\
\text { cious metals, metals } \\
\text { clad with precious } \\
\text { metal, and articles } \\
\text { thereof; imitation jewel- } \\
\text { lery; coin }\end{array}$ & USA & Japan \\
& & & & \\
\hline
\end{tabular}

Table 5: Top Five Food and Ag Commodities for China (HS-6)

\begin{tabular}{|c|c|c|c|c|c|c|c|c|}
\hline $\begin{array}{l}\text { Anteced- } \\
\text { ents }\end{array}$ & $\begin{array}{l}\text { Conse- } \\
\text { quent }\end{array}$ & $\begin{array}{l}\text { Antecedent } 1 \\
\text { name }\end{array}$ & $\begin{array}{l}\text { Antecedent } 2 \\
\text { name }\end{array}$ & $\begin{array}{l}\text { Consequent } \\
\text { name }\end{array}$ & $\begin{array}{l}\text { Sup- } \\
\text { port }\end{array}$ & $\begin{array}{l}\text { Con- } \\
\text { fi- } \\
\text { dence }\end{array}$ & Lift & Count \\
\hline $\begin{array}{l}\{120220, \\
170490\}\end{array}$ & $\{120210\}$ & $\begin{array}{l}\text { Ground-nuts; } \\
\text { shelled, not } \\
\text { roasted or oth- } \\
\text { erwise cooked, } \\
\text { whether or not } \\
\text { broken }\end{array}$ & $\begin{array}{l}\text { Sugar confection- } \\
\text { ery; (excluding } \\
\text { chewing gum, in- } \\
\text { cluding white } \\
\text { chocolate), not } \\
\text { containing cocoa }\end{array}$ & $\begin{array}{l}\text { Ground-nuts; } \\
\text { in shell, not } \\
\text { roasted or oth- } \\
\text { erwise cooked }\end{array}$ & 0.3 & 0.81 & 2.33 & 593 \\
\hline $\begin{array}{l}\{120210, \\
170490\}\end{array}$ & $\{120220\}$ & $\begin{array}{l}\text { Ground-nuts; in } \\
\text { shell, not } \\
\text { roasted or oth- } \\
\text { erwise cooked }\end{array}$ & $\begin{array}{l}\text { Sugar confection- } \\
\text { ery; (excluding } \\
\text { chewing gum, in- } \\
\text { cluding white } \\
\text { chocolate), not } \\
\text { containing cocoa }\end{array}$ & $\begin{array}{l}\text { Ground-nuts; } \\
\text { shelled, not } \\
\text { roasted or oth- } \\
\text { erwise cooked, } \\
\text { whether or not } \\
\text { broken }\end{array}$ & 0.3 & 0.9 & 2.31 & 593 \\
\hline $\begin{array}{l}\{120210, \\
200310\}\end{array}$ & $\{120220\}$ & $\begin{array}{l}\text { Ground-nuts; in } \\
\text { shell, not } \\
\text { roasted or oth- } \\
\text { erwise cooked }\end{array}$ & $\begin{array}{l}\text { Vegetable prepa- } \\
\text { rations; mush- } \\
\text { rooms, prepared } \\
\text { or preserved oth- } \\
\text { erwise than by }\end{array}$ & $\begin{array}{l}\text { Ground-nuts; } \\
\text { shelled, not } \\
\text { roasted or oth- } \\
\text { erwise cooked, } \\
\text { whether or not } \\
\text { broken }\end{array}$ & 0.3 & 0.92 & 2.36 & 589 \\
\hline
\end{tabular}




\begin{tabular}{|l|l|l|l|l|l|r|r|r|}
\hline $\begin{array}{l}\{120220, \\
200310\}\end{array}$ & $\{120210\}$ & $\begin{array}{l}\text { Ground-nuts; } \\
\text { shelled, not } \\
\text { roasted or oth- } \\
\text { erwise cooked, } \\
\text { whether or not } \\
\text { broken }\end{array}$ & $\begin{array}{l}\text { Vegetable prepa- } \\
\text { rations; mush- } \\
\text { rooms, prepared } \\
\text { or preserved oth- } \\
\text { erwise than by } \\
\text { vinegar or acetic } \\
\text { acid }\end{array}$ & $\begin{array}{l}\text { Ground-nuts; } \\
\text { in shell, not } \\
\text { roasted or oth- } \\
\text { erwise cooked }\end{array}$ & 0.3 & 0.82 & 2.34 & 589 \\
\hline $\begin{array}{l}\{070320, \\
120210\}\end{array}$ & $\{120220\}$ & $\begin{array}{l}\text { Vegetables, alli- } \\
\text { aceous; garlic, } \\
\text { fresh or chilled }\end{array}$ & $\begin{array}{l}\text { Ground-nuts; in } \\
\text { shell, not roasted } \\
\text { or otherwise } \\
\text { cooked }\end{array}$ & $\begin{array}{l}\text { Ground-nuts; } \\
\text { shelled, not } \\
\text { roasted or oth- } \\
\text { erwise cooked, } \\
\text { whether or not } \\
\text { broken }\end{array}$ & 0.3 & 0.91 & 2.34 & 586 \\
\hline
\end{tabular}

The next section presents contextual methods, and discussions on how contextual analysis and AI can aid in detecting outlier events and understanding their effects.

\section{Outlier Events and Contextual AI}

Outlier events or uncertainty affects economic outcomes. Uncertainty can arise from natural disasters, health pandemics or market disruptions as in the recent trade war between U.S. and China. Such uncertainty sets in motion a cascade of events: price changes, behavioral changes by producers and consumers, shipping and transportation issues, worker welfare and others. Moreover, the strength of cascading events varies by product or region of analysis. The three most critical adverse world incidents since the 1870s were World War II, the Great Depression in America, and World War I. Results from multiple studies suggest that the Great Influenza Pandemic of 1918-1920 is the next most important negative economic shock for the world (Barro et al., 2020). Not all outliers are created equal; the historical record suggests that the 1918 influenza was an outlier among outliers, with unusual circumstances including the co-occurrence of World War I. No other influenza pandemic on record had such devastatingly high mortality rates, with estimates ranging from 20 to 50 million excess deaths over the period 1918-20 (Fan et al., 2020). The ongoing Covid-19 pandemic is likely to be the next big outlier. Prior to Covid-19, researchers at the U.S. Centers for Disease Control and Prevention (CDC) calculate (using traditional models) that deaths in the United States could reach 207,000 and the initial cost to the economy could 
approach $\$ 166$ billion, or roughly 1.5 percent of GDP in case of an international pandemic similar to the 1918 outbreak (Garrett, 2008).

Modeling and predicting the implications of such outlier events is an important endeavor. During these outlier events, analysis is performed in uncharted waters. Issues arise such as the need to use daily if not hourly data (but not monthly data) for pattern recognition and predictions. Additionally, decisions become timelier and need to be executed in a quick manner using real time analysis and on-demand analytics.

AI methods are ideal in this context to not only help understand the impact of uncertainty or outliers but also provide on-time information to economic agents including policy makers.

Deploying context (a prominent field within $\mathrm{AI}$ ) to represent outlier events is complex but appropriate for the current coronavirus pandemic. The context within a dataset can be represented as features (Turney, 2002). Features in general fall into three categories: primary features, irrelevant features, and contextual features. Primary features are the traditional ones which are pertinent to a particular domain. Irrelevant features are features which occur randomly and can be safely removed, while contextual features are the ones to pay close attention to. The above categorization helps in eliminating irrelevant data but additional work is needed to clearly define context: Recognition and Exploitation of Contextual Clues via Incremental Meta-Learning, IML (Widmer, 1996), which is a two-level learning model in which a Bayesian classifier is used for context classification, and meta algorithms are used to detect contextual changes. An alternative to IML is context-sensitive feature selection (Domingos, 1997), which out performs traditional feature selection such as forward and backward sequential selection. Dominogos's (1997) method uses a clustering approach to select locally-relevant features.

Bergadano et al. (1992) introduced a two-tier contextual classification adjustment method called POSIEDON. The first tier captures the basic properties of context, and the second tier captures property modifications and context dependencies. Context injections however, have been more successful when they are applied to specific domains. For example, adding context to data has significantly improved the accuracy of algorithms for solving Natural Language Processing (NLP) problems. Dinh et al. (2012) combined the output from the classifier with a set of words manually labeled with context. A transformation-based learning algorithm was then used to generate new rules for the classifier. Their approach increased the contextual accuracy of their application by $4.8 \%$ as well as in software testing, i.e. significant improvements in time and quality of testing results due to context (Batarseh, 2014). 
The issue of deriving context from data for outlier detection however, is challenging since Williams (2018) pointed out that data science algorithms could have an opacity problem when ignoring the context. This can cause models to be racist or sexist (for example). It is often observed that Google translator refers to women as 'he said' or 'he wrote' when translating from Spanish to English. This finding was also verified by Google Inc. Another opacity example is a word embedding algorithm which classifies European names as pleasant and African American names as unpleasant (Zou et al., 2018). If a reductionist approach is considered, adding or removing data can surely redefine context, especially in the case of outlier events. It is observed however, that most real-world data science projects use incomplete data (Sesa and Syed, 2016) (Kang, 2013). Data incompleteness occurs within one of the following categorizations: 1) Missing Completely at Random (MCAR), 2) Missing at Random (MAR), and 3) Missing not at Random (MNAR). MAR depends on the observed data, but not on unobserved data while MCAR depends neither on observed data nor unobserved data (Schafer and Graham, 2002) (Graham, 2009). There are various methods to handle missing data issues which includes list wise or pair wise detections, multiple imputation, mean/median/mode imputation, regression imputation, as well as learning without handling missing data.

All the aforementioned methods require high quality data, since several types of bias can occur in any phase of the data science lifecycle or while extracting context. Bias can begin during data collection, data cleaning, modeling, or any other phase. Biases which arise in the data are independent of the sample size or statistical significance, and they can directly affect the context of the results or the model. They also affect the association between variables, and in extreme cases, they can even reflect the opposite of a true association or correlation (Pannucci, 2010). Based on reviewing multiple works in data science, the most commonly observed bias is class imbalance due to covariate shifts. Class imbalance is represented by the un-equal ratio of categories which can occur due to changes in the distribution of data (covariate shifts). Class imbalance depends on four factors: 1) degree of class imbalance 2) the complexity of the concept represented by the data 3) the overall size of the training size and 4) the type of classifier (Japkowicz, 2002). Datasets with imbalance create difficulties in information retrieval, filtering tasks, and knowledge representation (Lewis and Ringuette, 1994) (Lewis and Catlett, 1994) - which (if not accounted for) may lead to misinformation in the agricultural or economic domain. We aim to explore with the mentioned methods and test them along with the presented AI methods during conventional and outlier times. For instance, variations of RL methods can lead to pointers in causality and endogeneity. Injecting contextual data from outlier events (i.e. relevant to a black swan situation such as 
the Covid-19 pandemic) would lead to retraining of the models in a manner that would influence the patterns found. DL and RL models have the ability to seamlessly include outlier data and use it for predictions and classifications; a notion that we intend to explore and experiment with in our future work.

\section{Traditional Economics and Other Conclusions}

This study proposed a novel approach to understanding international trade patterns using AI methods. While traditional trade studies for over a century have provided important insights, the emerging big data environment and ongoing outlier events necessitate a nimbler and data-driven approach. First, we laid out AI methods appropriate for predicting trade patterns: Linear Regression, K-means clustering, Pearson correlations, Time Series such as Autoregressive Integrated Moving Average (ARIMA), and supervised and unsupervised AI methods. Applying these methods to agricultural products and using beef as example, we demonstrated that $\mathrm{AI}$ methods provide improved predictions relative to traditional models. Within this application, clustering major economies provided even better predictions. Next, we outlined association rules that can identify paired purchases in international trade. Using aggregated trade data, we demonstrated that such rules can identify complementarities and substitutability in international trade transactions. Finally, we showed how contextual AI's classification of features into regular, irregular and contextual along with bias elimination can aid in modeling the recent outlier events like the trade war and Covid-19 pandemic. Results from the big data framework are aimed to be presented in data dashboards to the farmer to update them on daily events during outliers, and to policy makers at agricultural agencies. A sample example of what we envision a farm dashboard would be is illustrated in Figure 7. Such dashboards allow farmers to take decisions on irrigation, seeding, weather modeling, among many other timely frequent decisions.

A key objective of quantitative economic analyses is to uncover relationships - e.g. demand, supply, prices or trade - for use in making predictions or forecasts of future outcomes. However, when the current systems generates forecasts for decision making, they require a range of ad hoc, expert-driven or a combination of simple forecasting models supplemented by subject matter expertise to econometricsbased methods and mega-models, i.e. applied general equilibrium. Employing such approaches, many international institutions and government agencies project economic variables including trade flows to 
inform decisions in national and multilateral contexts (such as the World Economic Outlook - International Monetary Fund).

These predictions are highly valued by producer and consumer groups as well as policymakers in making decisions. However, some of these predictions based on a combination of simple linear models and expert judgment, have limitations (Isengildina-Massa et al. 2011). Little guidance exists on theoretical modeling of trade policy uncertainty and its implications for producer and consumer behavior. As a result, ad hoc approaches to incorporating uncertainty can create specification bias in quantifying economic relationships and consequently, less precise outcomes on future agricultural trade patterns. The later, i.e. less precise forecasts, impacts producer and consumer decisions as well as government expenditures. These mega-models draw information from a variety of sources, e.g. elasticities, which can introduce additional specification errors or mismatch data distributions.

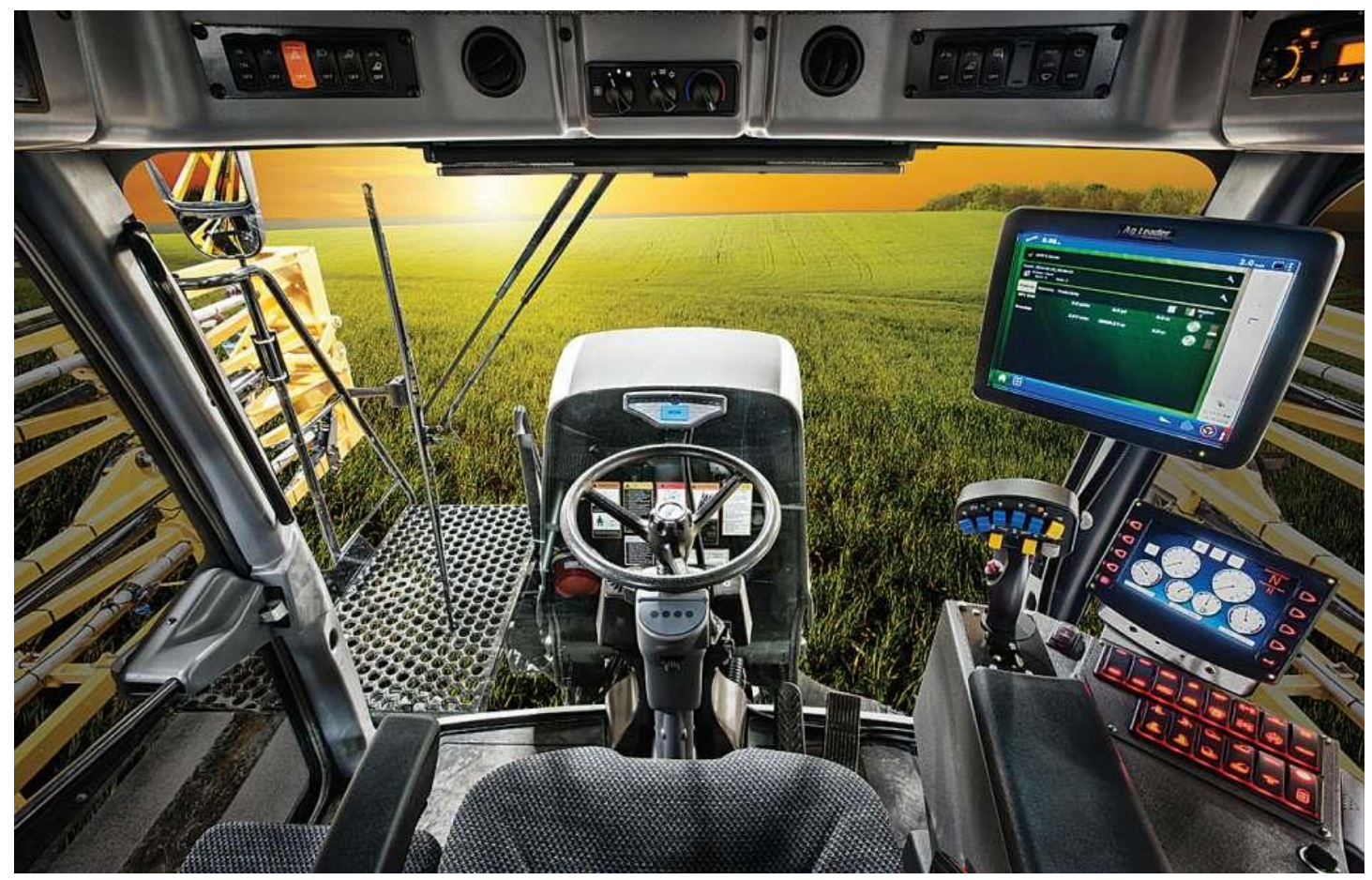

Figure 7: Precision Agriculture Tools for Farmers during Outlier Events (Sfiligo, 2016)

In sum, traditional models - ad hoc, econometrics or mega-models - have been challenged both on modeling uncertainties, and providing accurate and on-time information for policy and decision making. AI methods have the ability to provide solutions to these drawbacks. While better predictions are a key ingredient in decision-making of economic agents and public officials, the AI approaches can address 
additional dimensions not necessarily dealt with in traditional studies. For instance, there has been a challenge to achieve consensus at international bodies such as the United Nations, World Trade Organization and others since 2000. For instance, the Doha round of multilateral trade negotiations initiated in 2001 has not been concluded as of today. Some have argued that G20, a group of 20 nations that account for much of world's GDP and population, has become increasingly assertive on multilateral policies. For instance, In Annex II of G20's Strategy for Global Trade Growth (SGTG, 2020), the G20 declares developing a world trade outlook indicator, and promoting further e-commerce development. That includes an initiative on an electronic World Trade Platform (e-WTP). The AI models illustrated in this paper can allow for contrasting between decisions made by G20 versus engaging all countries like at the United Nations. In sum, the experimental work in this article indicates the high relevance of AI for predicting trade patterns with a greater accuracy than traditional approaches. Future work will expand the scope of commodities as well as AI methods, e.g. causality and reinforcement learning, to simulate trade outcomes under alternative policy scenarios including outlier events in recent times.

\section{References}

1. Batarseh, F.; and Yang, R. 2018. Federal Data Science: Transforming Government and Agricultural Policy using Artificial Intelligence. Elsevier's Academic Press. ISBN: 0128124431.

2. Batarseh, F., Yang, R, 2020. Data Democracy: At the Nexus of Artificial Intelligence, Software Development, and Knowledge Engineering. Elsevier's Academic Press. ISBN: 9780128183663.

3. The White House. 2008. Open Data Initiative.

4. Gevel, J.; and Noussair, C. 2013. The Nexus between Artificial Intelligence and Economics. Springer Briefs in Economics. DOI: 10.1007/978-3-642-33648-5_1

5. Gunning, D. 2017. Explainable Artificial Intelligence. DARPA's update on XAI.

6. National Bureau of Economic Research (NBER), Available from: https://www.nber.org/

7. Reddy, C.; Aggarwal, C. 2015. Healthcare Data Analytics. Taylor and Francis Group CRC Press. ISBN: 1482232111.

8. Batarseh, F., and Latif., E. 2015. Assessing the Quality of Service Using Big Data Analytics: With Application to Healthcare. Journal of Big Data Research. ISSN: 2214-5796. Vol. 4. pp. 1324 
9. Niemi, D.; Pea, R.; Saxberg, B.; Clark, R. 2018. Learning Analytics in Education. Information Age Publishing. ISBN: 978-64113-369-2.

10. Alamar, B. 2013. Sports Analytics. Columbia University Press. ISBN: 0231162928.

11. Storm, H.; Baylis, K.; Heckelei, T. 2019. Machine Learning in Agricultural and Applied Economics. Proceedings of the European Review of Agricultural Economics.

12. Feng, L.; Zhang, J. 2014. Application of Artificial Neural Networks in Tendency Forecasting of Economic Growth. Proceedings of Economic Modeling. pp. 76.80

13. Abadie, A.; Diamond, A.; Hainmueller, J. 2010. Synthetic Control Methods for Comparative Case Studies: Estimating the Effect of California's Tobacco Control Program. Journal of the American Statistical Association. Vol. 105. pp. 493-505.

14. Milacic, L.; Jovic, S.; Vujovic, T.; Miljkovic, J. 2016. Application of Artificial Neural Network with Extreme Learning Machine for Economic Growth Estimation. Elseviers Journal of Physica: Statistical Mechanics and its Applications. pp. 285-288.

15. Kordanuli, B.; Barjaktarovic, L.; Jeremic, L.; Alizamir, M. 2016. Appraisal of Artificial Neural Network for Forecasting of Economic Parameters. Elseviers Journal of Physica: Statistical Mechanics and its Applications. pp. 515-519.

16. Falat, L.; Pancikova, L. 2015. Quantitative Modelling in Economics with Advanced Artificial Neural Networks. Proceedings of the Business Economics and Management Conference. pp. 194-201.

17. Barro, R., Ursúa, J., and Weng, J. The Coronavirus and the Great Influenza Pandemic: Lessons from the "Spanish Flu" for the Coronavirus's Potential Effects on Mortality and Economic Activity. NBER Working Paper No. 26866. 2020. JEL No. E1,I0,O4

18. Sullivan, K., China's tariffs on Australian barley could see export market lose hundreds of millions of dollars, 2020, ABC news report, Available at: https://www.abc.net.au/news/2020-0519/barley-china-australia-tariffs-trade-dispute-explained/12263298

19. Eichenbaum, M., Rebelo, S., and Trabandt, M. The Macroeconomics of Epidemics. NBER Working Paper No. 26882. 2020. JEL No. E1,H0,I1

20. Fan, V., Jamison, D., and Summers, L., The Inclusive Cost of Pandemic Influenza Risk. Working Paper 22137. National Bureau of Labor Statistics (NBER). JEL No. H51,I15,I18

21. Center for Disease Control and Prevention, Available at: http://www.cdc.gov, 2019

22. Foreign Agricultural Service. 2019. Available from: https://apps.fas.usda.gov/Gats/default.aspx 
23. World Bank, WITS. 2019. Available from: https://wits.worldbank.org/

24. Python Libraries. 2019. Available from: https://docs.python.org/3/library/index.html

25. Ke, G.; Meng, Q.; Finley, T.; Wang, T.; Chen, W.; Ma, W.; Ye, Q.; and Liu, T. 2017. LightGBM: A Highly Efficient Gradient Boosting. $31^{\text {st }}$ Conference on Neural Information Processing Systems (NIPS). pp. 1-9

26. Piatetsky-Shapiro G. Discovery, Analysis, and Presentation of Strong Rules. From Knowledge Discovery in Databases. 1991. ISBN: 978-0-262-66070-9.

27. Piatetsky-Shapiro, WJ Frawley (eds.), Knowledge Discovery in Databases. AAAI/MIT Press, Cambridge, MA. 1991.

28. Agrawal R, Imielinski T, Swami A. Mining Association Rules between Sets of Items in Large Databases. In Proceedings of the 1993 ACM SIGMOD International Conference on Management of Data, pp. 207-216. ACM Press. URL: http://doi.acm.org/10.1145/170035.170072. (1993).

29. Turney, P.D., 2002. The management of context-sensitive features: A review of strategies. In 13th International Conference on Machine Learning, Workshop on Learning in Context-Sensitive Domains, Bari, Italy, pp. 60-66.

30. Widmer, G., 1996. Recognition and exploitation of contextual clues via incremental meta-learning (Extended version). In The 13th International Conference on Machine Learning, Morgan Kaufmann, San Francisco, pp. 525-533.

31. Domingos, P., 1997. Context-sensitive feature selection for lazy learners. In Lazy learning, pp. 227-253. Springer, Dordrecht.

32. Bergadano, F., Matwin, S., Michalski, R.S. and Zhang, J., 1992. Learning two-tiered descriptions of flexible concepts: The POSEIDON system. In Machine Learning, Vol. 8(1), pp. 5-43.

33. Dinh, P.H., Nguyen, N.K. and Le, A.C., 2012. Combining statistical machine learning with transformation rule learning for Vietnamese word sense disambiguation. In Computing and Communication Technologies, Research, Innovation, and Vision for the Future (RIVF), pp. 1-6.

34. Batarseh, F.A., 2014. Context-driven testing on the cloud. In Context in Computing, pp. 25-44. Springer, New York, NY.

35. Mary-Anne Williams, 2018. Risky bias in artificial intelligence. The Australian Academy of Technology and Engineering. Retrieved from: https://www.atse.org.au/content/news/risky-biasin-artificial-intelligence.aspx 
36. Zou, J. and Schiebinger, L., 2018. AI can be sexist and racist -it's time to make it fair. Retrieved from: https://www.nature.com/articles/d41586-018-05707-8

37. Sessa, J. and Syed, D., 2016. Techniques to deal with missing data. In Electronic Devices, Systems and Applications (ICEDSA) 5th International Conference, pp. 1-4.

38. Kang, H., 2013. The prevention and handling of the missing data. In Korean journal of anesthesiology, Vol. 64(5), pp. 402-406.

39. Schafer, J.L. and Graham, J.W., 2002. Missing data: our view of the state of the art. In Psychological meth-ods, Vol. 7(2), pp. 147.

40. Graham, J.W., 2009. Missing data analysis: Making it work in the real world. In Annual review of psychology, Vol. 60, pp. 549-576.

41. Pannucci, C.J. and Wilkins, E.G., 2010. Identifying and avoiding bias in research. In Plastic and reconstructive surgery, Vol. 126 (2), pp. 619.

42. Japkowicz, N. and Stephen, S., 2002. The class imbalance problem: A systematic study. In Intelligent data analysis, Vol. 6(5), pp. 429-449.

43. Lewis, D.D. and Ringuette, M., 1994. A comparison of two learning algorithms for text categorization. In Third annual symposium on document analysis and information retrieval, Vol. 33, pp. 81-93.

44. Lewis, D.D. and Catlett, J., 1994. Heterogeneous un-certainty sampling for supervised learning. In Machine Learning, 1994, pp. 148-156

45. Gopinath, M., Batarseh, F.A., and Beckman, J. Machine Learning in Gravity Models: An Application to Agricultural Trade. NBER Working Paper No. 27151. May 2020.

46. Sfiligo, E. 2016. Precision Agriculture: Top 10 technologies. Available at: https://www.therobotreport.com/top-10-technologies-in-precision-agriculture/

47. SGTG, 2020, In Annex II of G20’s Strategy for Global Trade Growth. Available at: https://trade.ec.europa.eu/doclib/docs/2016/july/tradoc_154789.pdf

48. Isengildina-Massa, O., S. Irwin, D.L. Good, and L. Massa. Empirical confidence intervals for USDA commodity price forecasts. Applied Economics 43:3789-3803. (2011). 